\title{
PERAN KANTOR WILAYAH KEMENTERIAN HUKUM DAN HAK ASASI MANUSIA TERHADAP PENDAFTARAN INDIKASI GEOGRAFIS
}

\author{
Erick Junata Sipayung* \\ Kanwil Kemenkumham Kepri
}

\begin{abstract}
Directorate General of Intellectual Property through the Regional Office of the Ministry of Law and Human Rights of Riau Islands Province has committed to continue to explore the Georaphical Indication's (GI) potential in each region through the Annual Performance Target. GI legal protection can only be given if an item or product has been registered, for example "Sagu Lingga" which has just been declared as one of the GI products. The results of research find that there is an effort to register potential IG Products in Riau Islands Province. In this regard, the effective role of the Kemenkumham Kepri Regional Office is questioned since the role is still limited to inventory, coordination with local governments and supervision of IG products.. The research finds that Kemenkumham Kepri Regional Office face several constraints pertaining to GI registration and protection, namely Legal Factors, Law Enforcement Factors, Means and Infrastructure Factors, Community Factors and also Cultural Factors.

Keywords: Regional Office Of The Ministry Of Law And Human Rights Of The Riau Islands, registration, geographical indication
\end{abstract}

\begin{abstract}
Abstrak
Ditjen Kekayaan Intellectual melalui Kanwil Kemenkumham Provinsi Kepulauan Riau telah berkomitmen untuk terus menggali potensi IG di setiap daerah melalui Target Kinerja Tahunan. Perlindungan hukum IG hanya dapat diberikan apabila suatu barang atau produk telah didaftarkan, contohnya "Sagu Lingga" yang baru saja dinyatakan sebagai salah satu produk IG. Dari hasil penelitian diperoleh bahwa terdapat upaya pendaftaran potensi Produk IG di Provinsi Kepulauan Riau. Sehubungan dengan hal tersebut, peran efektif Kanwil Kemenkumham Kepri dipertanyakan karena perannya masih terbatas pada inventarisasi, koordinasi dengan pemerintah daerah serta pengawasan produk IG. Penelitian ini menemukan bahwa Kantor Wilayah Kemenkumham Kepri menghadapi beberapa kendala yang berkaitan dengan pendaftaran dan perlindungan IG, yaitu Faktor Hukum, Faktor Penegakan Hukum, Faktor Sarana dan Infrastruktur, Faktor Komunitas dan juga Faktor Budaya.

Kata Kunci : Kantor Wilayah Kementerian Hukum Dan HAM Provinsi Kepulauan Riau, pendaftaran, indikasi geografi
\end{abstract}

*Alamat Korespondensi : erjun.sip@gmail.com 


\section{A. Latar Belakang Masalah}

Sebagai sebuah negara yang dijuluki negara megadiversitas ${ }^{1}$, Indonesia tentunya memiliki keanekaragaman hayati yang melimpah. Disamping itu Indonesia juga memiliki kebudayaan yang sangat beragam, akibatnya Indonesia memiliki kekayaan bukan saja di bidang sumber daya alam namun juga kaya atas keanekaragaman budayanya. Sumber daya alam serta kebudayaan tersebut merupakan aset yang dapat diberdayakan sedemikian rupa dalam rangka meningkatkan kesejahteraan rakyat. Terjadinya era globalisasi telah mendorong terciptanya laju pertumbuhan perekonomian di masyarakat. Begitu juga dengan terjadinya peningkatan di bidang teknologi informasi dan transportasi telah berdampak pada meningkatnya aktifitas perdagangan secara pesat. Kecenderungan peningkatan ini akan terus berlanjut seiring dengan meningkatnya pertumbuhan manusia baik dari segi kualitas maupun kuantitas. Perdagangan barang/produk yang merupakan hasil dari kemampuan intelektualitas manusia pun akan semakin berkembang. Menghadapi fakta tersebut, maka adalah suatu keharusan bagi munculnya peraturan yang memayungi persoalan terkait perlindungan terhadap kekayaan intelektual. Selama ini masyarakat mengenal paten, informasi rahasia/rahasia dagang, cipta dan hak kekayaan intelektual yang lainnya sebagai rezim dari hak kekayaan intelektual. Sementara masyarakat masih awam dengan istilah Indikasi Geografis (IG) yang juga merupakan bagian dari kekayaan intelektual. IG adalah nama dagang yang diidentikkan, digunakan atau dilabelisasi pada sebuah produk yang digunakan untuk menunjukkan tempat dimana produk dimaksud berasal. Tempat asal tersebut menandakan bahwasanya kualitas suatu produk IG sangat dipengaruhi oleh tempat asalnya, dengan demikian produk tersebut menjadi memiliki nilai yang unik bagi masyarakat, lebih khusus lagi oleh konsumen.

Di tahun 2016 pemerintah mengeluarkan Undang-Undang Nomor 20 Tahun 2016 tentang Merek dan IG (UU Nomor 20 Tahun 2016 tentang Merek dan IG). Akibat dikeluarkannya Undang-Undang ini maka Undang-Undang yang sudah ada sebelumnya yaitu Undang-Undang Nomor 15 Tahun 2001 tentang Merek (UU Nomor 15 Tahun 2001 tentang Merek) dinyatakan dicabut dan tidak berlaku lagi. Meskipun Undang-Undang ini telah diundangkan pada tahun 2016 dan mengamanatkan untuk membuat peraturan pelaksanaannya 2 (dua) tahun terhitung sejak diundangkan, namun kenyataannya produk hukum turunannya baru

\footnotetext{
${ }^{1}$ Negara megadiversitas merupakan negara di dunia yang mempunyai keanekaragaman hayati terbanyak. Beberapa negara di dunia yang kaya akan keanekaragaman hayatinya ini diklaim sebagai pemilik hampir sebagian besar keanekaragaman hayati yang ada di dunia. Pusat Pengamatan Konservasi Dunia (World Conservation Monitoring Centre), sebuah badan dalam Program Lingkungan Hidup Perserikatan Bangsa-Bangsa (United Nations Environment Programme), telah mengidentifikasi 17 negara megadiversitas, yang biasanya berlokasi di kawasan tropis. Adapun ketujuhbelas negara tersebut adalah; Australia, Brazil, Republik Rakyat Tiongkok, Kolombia, Republik Demokratik Kongo, Ekuador, India, Indonesia, Madagaskar, Malaysia, Meksiko, Papua Nugini, Peru, Filipina, Afrika Selatan, Amerika Serikat dan Venezuela.
} 
diterbitkan pada pertengahan tahun 2019 yaitu berupa Permenkumham Nomor 12 Tahun 2019 tent ang IG (Permenkumham Nomor 12 Tahun 2019 tentang IG). Oleh karena itu Peraturan Pemerintah Nomor 51 Tahun 2007 tentang IG masih dijadikan pedoman terutama dalam hal prosedur pendaftaran IG dan peninjauan substanstif. Perlindungan IG berdasarkan Undang-Undang Nomor 20 Tahun 2016 didasarkan pada pendaftaran. Sebagaimana dinyatakan dalam Pasal 53 ayat (1) bahwa terlindunginya suatu IG setelah IG tersebut didaftarkan kepada Menteri Hukum dan Hak Asasi Manusia Republik Indonesia.

Kantor Wilayah Kementerian Hukum dan Hak Asasi Manusia Kepulauan Riau (Kanwil Kemenkumham Kepri) merupakan salah satu provinsi yang ada di Indonesia merupakan perpanjangan tangan pusat di daerah memiliki kewenangan dan fungsi terhadap pelayanan kekayaan intelektual termasuk Kekayaan Intelektual (KI) komunal yang di dalam nya termasuk IG juga mempunyai tugas dan tanggung jawab dalam melaksanakan pembinaan dan pengawsan terhadap IG sebagaimana yang diamanatkan dalam peraturan perundang-undangan yang terkait dengan IG. Sehingga secara otomatis diperlukan peran konkrit Kanwil dalam mewujudkan pelindungan IG melalui pendaftaran potensi IG yang tersebar di seluruh hamparan air dan tanah Kepulauan Riau.

Provinsi Kepulauan Riau (Kepri) merupakan salah satu Provinsi paling muda di Indonesia. Provinsi yang ditetapkan berdasarkan Undang-Undang Nomor 25 Tahun 2002 tentang Pembentukan Provinsi Kepulauan Riau saat ini terdiri dari 7 (tujuh) kabupaten/kota yaitu; Kabupaten Natuna, Kabupaten Bintan, Kabupaten Lingga, Kabupaten Karimun, Kabupaten Anambas, Kota Tanjungpinang dan Kota Batam. Provinsi yang hanya (5\% lima persen) wilayahnya merupakan daratan ini mengandung sumber daya alam mineral dann sumber daya energi yang begitu melimpah, diantaranya berupa bahan galian, gas alam, kuarsa, timah, minyak bumi, pasir, bauksit, granit, dan pasir besi. Dari segi pertanian Kepri juga menyimpan beragam potensi untuk dikembangkan. Selain palawija juga hortikultura, tanaman lainnya seperti nenas, kelapa, cengkih, gambir, serta kopi amat baik untuk budidayakan. Demikian pula halnya dengan Kabupaten Bintan dan Lingga sangat baik jika ditanami sayuran dan buah-buahan. Bahkan di beberapa pulau sangat baik untuk ditanami kelapa sawit, padi, atau merica. Sementara itu 95\% (sembilan puluh lima persen) wilayah Kepri yang merupakan lautan tentu menyimpan kekayaan yang melimpah dan apabila dioleh sedemikian rupa dapat menjadi potensi produk IG. Di tengah melimpahnya potensi produk IG yang didapati di Kepri, ironisnya hingga kini, Provinsi Kepri baru memiliki 1 (satu) produk IG terdaftar yaitu tepung sagu Lingga. Realitas ini menyisakan pertanyaan sejauh mana urgensi pendaftaran Potensi IG yang bisa didapati di Provinsi Kepri, dan sejauh mana peran Kanwil Kemenkumham Kepri dalam mendorong upaya pendaftaran potensi IG agar potensi tersebut dapat terlindungi demi mendorong meningkatnya taraf kesejahteraan masyarakat. Berdasarkan apa yag diuraikan di ataslah yang mendorong penulis untuk melakukan sebuah penelitian yang diberi judul "Peran Kantor Wilayah Kementerian Hukum Dan Hak Asasi Manusia Terhadap Pendaftaran Potensi Indikasi Geografis". 


\section{B. Rumusan Masalah}

Berdasarkan latar belakang tersebut di atas maka dalam penelitian ini terdapat beberapa rumusan masalah yang hendak dicari jawabannya, yaitu:

1. Bagaimana peran Kantor Wilayah Kementerian Hukum dan Hak Asasi Manusia Kepulauan Riau terhadap pendaftaran potensi Indikasi Geografis?

2. Apa saja kendala yang dihadapi Kantor Wilayah Kementerian Hukum dan Hak Asasi Manusia Kepulauan Riau dalam upaya pendaftaran potensi Indikasi Geografis?

3. Bagaimana solusi untuk mengatasi kendala yang dihadapi oleh Kantor Wilayah Kementerian Hukum dan Hak Asasi Manusia Kepulauan Riau dalam pendaftaran potensi Indikasi Geografis?

\section{Metode Penelitian}

Penelitian dilakukan bertujuan menganalisis rumusan permasalahan di atas, dilakukan melalui metode Yuridis Sosiologis. Yuridis sosiologis ialah penelitian hukum dengan menggunakan data sekunder sebagai data awalnya, kemudian dilanjutkan dengan menggunakan data primer atau data lapangan, meneliti penerapan suatu peraturan pemerintah dan penelitian yang bertujuan mencari keterkaitan (korelasi) antara berbagai gejala atau variabel, dengan menggunakan studi dokumen, pengamatan (observasi) dan wawancara (interview) sebagai alat pengumpul datanya. ${ }^{2}$

Melalui metode pendekatan yuridis sosiologis, maka penerapan suatu hukum (Das Sein), yang pada penelitian ini adalah UU Nomor 20 Tahun 2016 tentang Merek dan IG, PP Nomor 51 Tahun 2007 tentang IG serta Permenkumham RI Nomor 12 Tahun 2019 tentang IG diarahkan untuk melihat pada kenyataan berjalannya hukum di tengah masyarakat. Peneliti menggunakan jenis penelitian hukum tersebut dimaksudkan untuk mengamati terjadinya gape yaitu kesenjangan hukum antara apa yang dicita-citakan (Das Sollen) terhadap kenyataan hukum (Das Sein) terkait dengan hak atas IG di Provinsi Kepri. Untuk menjawab permasalahan pada penelitian ini, maka ada beberapa tahap penelitian yang akan dilakukan oleh peneliti yaitu melaksanakan penelitian di Kanwil Kemenkumham Kepri dan meneliti peraturan perundang-undangan yang berhubungan dengan IG.

Penggunaan data primer dan sekunder dalam sebuah penelitian sosiologis adalah suatu hal yang lumrah. Oleh karenanya dalam penelitian ini penulis menggunakan data tersebut yang terdiri dari:

\section{a. Data Primer}

Penelitian ini dilakukan pada Kemenkumham Kepri, Dinas Pertanian dan Ketahanan Pangan Kabupaten Lingga, serta instansi/dinas lainnya yang merupakan instansi yang secara langsung berkaitan dengan pendaftaran potensi IG berupa

${ }^{2}$ Amiruddin, Pengantar Metode Penelitian Hukum, Jakarta: PT. Raja Grafindo Persada, 2012, hlm. 34. 
barang/produk potensi IG yakni Tepung Sagu Lingga. Pengumpulan data akan dilakukan dengan melakukan wawancara serta melakukan pengamatan pada Kanwil Kemenkumham Kepri serta Dinas Pertanian dan Ketahanan Pangan Kabupaten Lingga serta instansi terkait lainnya.

Sampel ditentukan berdasarkan atas konsiderasi bahwa "purposive sampling"3 diketahui sebagai teknik dengan melakukan pertimbangan- pertimbangan tertentu untuk mengambil sampel dari sumber data yaitu sumber data yang diyakini paling tahu terkait informasi apa saja yang diharapkan, sehingga memudahkan peneliti dalam menjelajahi objek maupun situasi yang sedang diteliti, sehingga sampel dimaksud telah dinilai cukup untuk merepresentasikan terbentuknya produk peraturan perundang-undnagan pada wilayah dimana objek diteliti.

\section{b. Data Sekunder, terdiri dari:}

1) Bahan Hukum Primer

Yaitu bahan hukum yang bersifat mengikat, yang terdiri atas peraturan perundang-undangan yang berkaitan dengan permasalahan. Dalam penelitian ini bahan-bahan yang berasal dari peraturan perundang-undangan merupakan bahan hukum primer yang terdiri dari:

a) Undang-Undang Nomor 20 Tahun 2016 tentang Merek dan IG;

b) Peraturan Pemerintah Nomor 51 Tahun 2007 tentang IG;

c) Peraturan Menteri Hukum dan Hak Asasi Manusia Republik Indonesia Nomor 12 Tahun 2019 tentang IG.

d) Keputusan Menteri Hukum dan Hak Asasi Manusia Republik Indonesia Nomor M.HH-01.PR.01.03 Tahun 2017 tentang Target Kinerja Kementerian Hukum dan Hak Asasi Manusia Tahun 2018.

2) Bahan Hukum Sekunder

Yaitu bahan Yaitu bahan-bahan yang dapat menjelaskan tentang bahan hukum primer. Yang menajdi bahan hukum sekunder pada penelitian ini ialah berupa buku-buku, majalah, jurnal, karya ilmiah, makalah laporan hasil penelitian lainnya yang berkaitan dengan obyek penelitian.

3) Bahan Hukum Tersier

Yaitu adalah bahan hukum yang dapat memberikan informasi dan penjelasan terhadap bahan hukum primer dan sekunder, seperti:, Kamus Besar Bahasa Indonesia (KBBI), Kamus Hukum, Kamus Bahasa Inggris, dan lainlain.

Metode pendekatan dan jenis data yang digunakan dalam penelitian ini disesuaikan untuk memperoleh data-data yang diperlukan. Oleh karena itu dalam penilitan ini digunakan teknik pengumpulan data melalui wawancara, observasi dan studi dokumen. Dalam penganalisisan data, sangat bergantung pada sifat data yang dihimpun oleh peneliti (pada tahap pengumpulan data). Mengolah serta menganalisis data dalam penelitian hukum sosiologis, tentu saja disesuaikan

\footnotetext{
${ }^{3}$ Purposive sampling adalah teknik pengambilan sampel sumber data dengan pertimbangan tertentu yakni sumber data dianggap paling tahu tentang apa yang diharapkan, sehingga mempermudah peneliti menjelajahi obyek atau situasi yang sedang diteliti, dalam Sugiyono, Metode Penelitian Kuantitatif Kualitatif dan R\&D, Bandung: Alfabeta, 2008, hlm. 218.
} 
dengan cara-cara penganalisisan data dalam ilmu sosial. Penelitian ini menggunakan metode analisis data dengan menggunakan metode pendekatan kualitatif, yakni dengan cara memadukan antara penelitian kepustakaan dan penelitian lapangan sebagai metode dalam pembahasan. Melakukan penelitian kepustakaan dengan cara mengkomparasi peraturan perundnag-undangan, ketentuan-ketentuan, dan buku-buku referensi/litratur serta data yang didapatkan, kemudian dianalisis sedemikian rupa secara kualitatif yang nantinya akan memberikan deskripsi yang komperehensif mengenai aspek hukum yang berkaitan dengan masalah yang diteliti. Terhadap data yang diperoleh dalam penelitian ini selanjutnya peneliti akan menganalisis berdasarkan metode yuridis kualitatif, melalui cara berpikir deduktif (umum-khusus), yaitu terhadap data-data yang didapatkan dijabarkan, ditafsirkan dan dikonstruksikan berdasar norma-norma atau kaidah-kaidah, teori-teori, pengertian-pengertian hukum dan doktrin-doktrin yang terdapat dalam dokumen Peraturan Perundang-undangan, sehingga mampu menjawab permasalahan yang ada. Tahap demi tahap data yang ada dianalisis, dengan demikian kebutuhan akan data yang dianggap masih kurang dalam penelitian ini dapat diketahui dengan cepat dan sesegera mungkin melengkapi kekurangan data dengan mengulang penelitian guna memperoleh data tambahan Selanjutnya mengenai permasalahan yang diangkat dalam penelitian ini, analisa dilakukan dengan cara menganalisis permasalahan yang ada di lapangan yakni sejauh mana peran Kanwil Kemenkumham Kepri yang merupakan perpanjagan tangan Kemenkumham RI di wilayah dalam hal memberikan pelayanan di bidang kekayaan intelektual khususnya terkait dengan pendaftaran potensi produk IG di Provinsi Kepri. Hal ini dilakukan dalam kaitan adanya praduga bahwa di dalam masyarakat telah terjadi kesenjangan antara "Das Sollen" atau yang dikenal pula sebagai hukum normatif dengan pelaksanaan norma-norma tersebut "Das Sein". Sebagai suatu gejala empiris hukum secara konsep sosiologis dapat dilihat melalui pengamatan dalam kehidupan. Setelah dilakukan analisis, maka hasil analisis tersebut akan disajikan dalam bentuk narasi deskriptif, yakni berupa uraian hasil temuan di lapangan tentang uraian permasalahan dalam penelitian dan selanjutnya menarik kesimpulan yang merupakan jawaban atas setiap rumusan permasalahan yang diangkat dalam penelitian ini.

\section{Hasil Penelitian Dan Pembahasan \\ a. Peran Kantor Wilayah Kementerian Hukum dan Hak Asasi Manusia Kepulauan Riau terhadap Pendaftaran Potensi Produk IG}

Peraturan perundang-undangan, mulai dari UU Nomor 20 Tahun 2016 tentang Merek dan IG, PP Nomor 51 Tahun 2007 tentang IG, Permenkumham RI Nomor 30 Tahun 2018 tentang ORTA Kanwil Kemenkumham RI, Permenkumham RI Nomor 12 Tahun 2019 tentang IG baik secara eksplisit maupun implisit telah mengamanatkan bahwa Kemenkumham RI memiliki tugas dan fungsi di bidang kekayaan intelektual. IG adalah salah satu bagian dari rezim kekayaan intelektual yang kepemilikannya bersifat komunal, otomatis menjadi domain tugas dan fungsi dari Kemenkumham RI. 
Kanwil kemenkumham sebagai perpanjangan tangan pusat di daerah merupakan satu di antara 34 kanwil yang tersebar di seluruh provinsi di Indonesia, melaksanakan tugas dan fungsi Kemenkumham di tingkat wilayah dalam hal ini di provinsi Kepri. Pelayanan di bidang kekayaan intelektual adalah salah satu doamin tugas dan fungsi yang mesti dilaksanakan oleh Kanwil kemenkumham Kepri.

Lahirnya UU Nomor 20 Tahun 2016 tentang Merek dan IG merupakan terobosan besar bagi perlindungan IG. Undang-Undang ini bukan saja secara nomenklatur telah mengakomodir IG karena telah menyematkan kata IG pada nama Undang-Undang tersebut namun pengaturannya dinilai telah mengatur tentang IG secara lebih luas dan komperehensif sehingga pengaturan mengenai IG tidak lagi dianggap sekedar pengaturan yang bersifat sekunder tapi telah sejajar dengan pengaturan tentang merek.

Namun pada kenyataannya, berdasarkan data yang diperoleh oleh peneliti, bahwa hingga dilakukannya penelitian ini, baru terdapat 1 (satu) barang/produk potensi IG yang telah didaftarkan dan mendapatkan sertifikat IG yaitu Tepung Sagu Lingga. Hal ini terbilang ironis karena sesungguhnya sebagai Provinsi yang terdiri dari 7 (tujuh) kabupaten/kota yang mayoritas wilayahnya terdiri dari lautan, Kepualaun Riau memiliki banyak sekali sumber daya alam, keanekaragaman hayati, budaya dan tradisi yang kesemuanya itu berpotensi untuk didaftarkan sebagai IG.

Untuk mengetahui sejauh mana peran dari Kanwil Kemenkumham Kepri terhadap keberhasilan pendaftaran potensi IG karena memang diamanatkan oleh Peraturan Perundang-undangan memiliki tugas dan fungsi dalam pelayanan kekayaan intelektual yang bukan sebatas merek, cipta paten dan sebagainya tapi termasuk di dalamnya pelayanan terhadap kekayaan intelektual komunal seperti Ekspresi Budaya Tradisional (EBT), Pengetahuan Tradisional (PT), Sumber Daya (SDG) Genetik dan IG maka peneliti melakukan penelitian pada Kanwil Kemenkumham Kepri, melakukan wawancara, studi dokumen maupun observasi, tidak hanya di pada Kanwil namun juga melakukan wawancara dengan pihak-pihak yang dianggap terkait dan potensial memberikan data serta informasi yang diperlukan untuk penelitian ini seperti wawancara dengan pejabat di Ditjen KI, Pejabat Dinas Pertanian dan Ketahanan Pangan Kabulaten Lingga, dengan Pengurus Perhimpunan Pendayaguna Sagu Lingga, dan pejabat pada intansi lainnya.

Dalam penelitian ini penulis telah mewawancarai narasumber yang berkaitan langsung dengan peran Kanwil Kemenkumham Kepri, khususnya dalam upaya pendaftaran potensi IG yang ada di Provinsi Kepri. Narasumber yang diwawancarai dalam penelitian ini adalah 12 (dua belas) orang, yaitu 4 (empat) perempuan dan 8 (delapan) laki-laki dan. Dari jumlah tersebut peneliti mewawancarai narasumber yang paling berkompeten yaitu pada Sub Dir.Merek dan IG Dirjen Kekayaan Intelektual Kemenkumham RI, Kadiv Yankum dan HAM Kanwil Kemenkumham Kepri, Kabid Pelayanan AHU dan Subbidang KI, Kasubbid Kekayaan Intelektual, Dinas Pertanian Kabupaten Lingga, Dinas Koperasi dan Usaha Mikro Kabupaten Lingga, Kepala Subbagian Produk Hukum Daerah Kabupaten Karimun, Dinas Pertanian Kabupaten Bintan dan Dinas Pertanian Kabupaten Natuna, Dinas 
Pertanian Kabupaten Kepulauan Anambas, dan Perhimpunan Pendayaguna Sagu Indonesia (PPSI) Cabang Kabupaten Lingga.

Selain melakukan wawancara kepada para narasumber, peneliti juga melakukan observasi secara langsung ke Kabupaten Lingga sebagai satu-satunya daerah di Provinsi Kepri yang baru memiliki produk IG yang telah di daftarkan pada Kemenkumham RI, yaitu produk "Sagu Lingga".

IG atau yang lebih populer dengan sebutan IG dewasa ini semakin dikenal di Indonesia, apalagi sejak diberlakukannya UU Merek dan IG. KI meliputi berbagai jenis antara lain Hak Cipta (copyrights), Kekayaan Industrial (industrial copyrights) yang terbagi atas Paten, Desain Industri, Merek, Penanggulangan Praktek Persaingan Curang (repression of unfair competition), Desain Tata Letak Sirkuit Terpadu (Iayout design of integrated circuit), rahasia dagang dan IG (geographical indications). ${ }^{4}$ Sebagai penyempurnaan atas UU No.15 Tahun 2001 tentang Merek, peraturan pelaksanaan dari UU Merek dan IG masih mengacu pada Peraturan Pemerintah No. 51 Tahun 2007, serta Permenkumham N. 12 Tahun 2019.

IG merupakan "suatu tanda yang menunjukkan daerah asal suatu barang, yang karena faktor lingkungan geografis termasuk faktor alam, faktor manusia atau kombinasi dari kedua faktor tersebut, memberikan ciri dan kualitas tertentu pada barang yang dihasilkan". ${ }^{5}$ Sebagai langkah konkrit pemerintah dalam melindungi berbagai produk khas Indonesia yang beranekaragam yang tersebar di berbagai daerah, pemerintah terus melakukan inventarisasi terhadap potensi produk yang dapat didaftarkan sebagai IG agar setiap pemilik produk tersebut menjadi pemegang Hak atas $\mathrm{IG}^{6}$ yang diakui secara legal. Secara konstitusional, jaminan perlindungan terhadap KI komunal seyogianya menjadikan landasan fundamental bagi pemerintah dalam menyusun kebijakan yang berorientasi pada kesejahteraan rakyatnya. Sebagai perpanjangan tangan dari Kementerian Hukum dan Hak Asasi Manusia Republik Indonesia, Kanwil Kemenkumham Kepri mempunyai peran ${ }^{7}$ yang cukup besar dalam upaya pendaftaran potensi produk IG yang ada di Provinsi Kepri khususnya di Kota Tanjungpinang, Kota Batam, Kabupaten Lingga, Kabupaten Karimun, Kabupaten Bintan, Kabupaten Kepulauan Anambas serta Kabupaten Natuna.

Namun, harus diakui bahwa sejak berlakunya undang-undang IG sampai dengan tahun 2019, baru terdapat 1 (satu) produk IG dari Kepri yang terdaftar pada Direktorat Jenderal Kekayaan Intelektual. Produk IG dimaksud adalah "Sagu

\footnotetext{
${ }^{4}$ Muhammad Firmansyah, Tata Cara Mengurus Hak Kekayaan Intelektual, Jakarta ; Visimedia, 2008, hlm.7.

${ }^{5}$ Berdasarkan ketentuan Pasal 1 angka 6 UU 20 Tahun 2016.

${ }^{6}$ Dalam Pasal 1, angka 7 UU 20 Tahun 2016, Hak atas IG dimaknai sebagai hak eksklusif yang diberikan oleh negara kepada pemegang hak IG yang terdaftar dalam daftar umum IG selama karakteristik khas dan kualitas yang menjadi dasar diberikannya perlindungan atas IG tersebut masih ada".

${ }^{7}$ Peran adalah kombinasi adalah posisi dan pengaruh.Seseorang melaksanakan hak dan kewajiban, berarti telah menjalankan suatu peran, diakses melalui http://umumpengertian.blogspot.com/2016/06/pengertian-peran-secara-umum.html, tanggal 12 November 2019.
} 
Lingga", dimana sesuai dengan namanya produk tersebut adalah berasal dari Kabupaten Lingga. Keberadaan Sagu Lingga sebagai produk IG secara resmi disampaikan melalui Pelaksana tugas (Plt) Gubernur Kepri pada tanggal 17 Oktober 2019 yang lalu, pencapaian ini tentu saja tidak terlepas dari peran Kanwil Kemenkumham Kepri yang dilakukan dengan kerjasama dan dukungan para pihak, terutama Pemerintah Daerah Kabupaten Lingga melalui Dinas Pertanian serta petani sagu yang tergabung dalam Perhimpunan Pendayaguna Sagu Indonesia (PPSI) Cabang Lingga.

Upaya perlindungan terhadap "Sagu Lingga" sebelum dikenal sebagai salah satu kekayaan intelektual komunal merupakan bentuk tanggungjawab dan perlindungan yang diberikan oleh Kemenkumham yang telah diamanatkan dalam ketentuan Pasal 53 ayat (1) dan ayat (2) UU Nomor 20 Tahun 2016 yang menyebutkan bahwa:

(1) "IG dilindungi setelah IG didaftar oleh Menteri"

(2) "Untuk memperoleh perlindungan sebagaimana dimaksud pada ayat (1), pemohon IG harus mengajukan permohonan kepada Menteri ${ }^{8}$.

Adapun yang berhak untuk menjadi pemohon IG sebagaimana dimaksud dalam rumusan diatas adalah :

a. "Lembaga yang mewakili masyarakat di kawasan geografis tertentu yang mengusahakan suatu barang/produk berupa:

1. sumber daya alam;

2. barang kerajinan tangan; atau

3. hasil industri." 9

b. "Pemerintah daerah provinsi atau kabupaten/kota". ${ }^{10}$

Sebagaimana diatur dalam PP No.51 Tahun 2007 alur pendaftaran IG adalah sebagai berikut:

a. Tahap pengajuan permohonan;

b. Tahap pemeriksaan administratif;

c. Tahap pemeriksaan substansi;

d. Tahap pengumuman;

e. Tahap oposisi pendaftaran;

f. Tahap pendaftaran; dan

g. Tahap pengawasan terhadap pemakaian IG.

Selanjutnya, untuk menentukan sejauh mana peran Kanwil kemenkumham Kepri dalam upaya pendaftaran potensi Produk IG yang ada di wilayah Kepri, peneliti melakukan analisis berdasarkan Teori Efektivitas Hukum yang

\footnotetext{
${ }^{8}$ Yang dimaksud dengan Menteri dalam ketentuan umum Pasal 1 angka 20, UU No.20 Tahun 2016 adalah, Menteri yang menyelenggarakan urusan pemerintahan di bidang hukum.

${ }^{9}$ Lihat Pasal 53 ayat (3) UU Nomor 20 Tahun 2016 tentang Merek dan IG.

${ }^{10}$ Dalam Pasal 1 angka 2, UU Nomor 23 Tahun 2014, Pemda adalah kepala daerah sebagai unsur penyelenggara Pemda yang memimpin pelaksanaan urusan pemerintahan yang menjadi kewenangan daerah otonom.
} 
dikemukakan oleh Soerjono Soekanto. Efektifitas hukum adalah suatu proses yang ditujukan agar supaya dapat berjalan secara efektif.

Apabila ingin mengetahui sejauh mana keberhasilan sebuah hukum yang berlaku di masyarakat, maka harus diketahui hukum itu ditaati oleh masyarakat yang menjadi target pengukuran keberhasilan atau justru tidak ditaati. Maka dengan demikian kita akan memperoleh jawaban bahwa aturan hukum tersebut berlaku efektif atau tidak efektif dalam masyarakat. Walaupun begitu, sekalipun suatu aturan yang ditaati itu bisa dikatakan telah efektif, tetapi tetap masih bisa dipertanyakan sejauh mana tingkat efektivitasnya karena dalam menaati suatu aturan hukum sangat tergantung pada kepentingan masing-masing orang. Suatu hukum dapat dikatakan efektif apabila ditemui dampak hukum yang positif, yang mana pada saat itu hukum mencapai sasarannya dalam membimbing atau merubah perilaku manusia menjadi perilaku hukum. Terkait dengan efektivitas hukum, juga terdapat unsur paksaan berkaitan erat dengan efektif atau tidaknya aturan hukum.

Adapun yang menjadi parameter efektifitas penegakan hukum menurut Soerjono Soekanto terdapat pada 5 (lima) hal, yakni Faktor hukumnya (undangundang), Faktor penegak hukumnya, Faktor sarana maupun prasarana (fasilitas yang mendukung penegakan hukum), faktor masyarakatnya (lingkungan yang merupakan tempat berlakunya suatu hukum atau aturan diterapkan), dan Faktor kebudayaan (yang merupakan hasil karya, cipta, rasa dan karsa manusia).

Seperti yang kita ketahui bersama bahwa sebagai di dalam era perdagangan global saat ini pemerintah telah meratifikasi konvensi intemasional dalam bidang perlindungan Kekayaan Intelektual. Lahirnya Undang-Undang Nomor 20 Tahun 2016 tentang Merek dan IG secara filosofis bertujuan untuk menjaga persaingan usaha yang sehat, mewujudkan keadilan, memberikan pelindungan kepada konsumen, serta Usaha Mikro, Kecil, dan Menengah (UMKM) dan industri dalam negeri. Selain tujuan tersebut, jika dilihat dari konsiderans menimbang undangundang tersebut bahwa pengaturan terhadap perlindungan IG yang diatur dari BAB VIII juga memiliki maksud untuk meningkatkan pelayanan dan mernberikan kepastian hukum bagi dunia industri, perdagangan, dan investasi dalam menghadapi perkembangan perekonomian lokal, nasionial, regional, dan internasional serta perkembangan teknologi informasi dan komunikasi. Dari paparan tersebut sebenarnya Undang-Undang Nomor 20 Tahun 2016 tentang Merek dan Indikasi Geofrafis sudah cukup baik.

Dalam kaitannya dengan peran Kantor Wilayah Kementerian Hukum dan Hak Asasi Manusia dalam upaya pendaftaran potensi produk IG yang dimulai dari tahap pendaftaran sebagaimana diatur daalam Pasal 53 ayat (1) dan ayat (2) yang menyebutkan bahwa:

(1) "IG dilindungi setelah IG didaftar oleh Menteri".

(2) "Untuk memperoleh pelindungan sebagaimana dimaksud pada ayat (1), Pemohon IG harus mengajukan Permohonan kepada Menteri".

Dalam Pasal 1 angka 20 UU 20/2016, kata "Menteri" dalam rumusan Pasal 53 ayat (1) dan (2) diatas, dibatasi dengan pengertian menteri yang menyelenggarakan urusan pemerintahan di bidang hukum. Sehingga jika dikaitkan dengan 
Permenkumham RI Nomor 30 Tahun 2018 tentang ORTA Kanwil Kemenkumham merupakan bagian dari unit kerja Kemenkumham yang merupakan perpanjangtanganan Menteri dalam memberikan perlindungan atas IG yang telah terdaftar. Hal ini sejalan dengan hasil wawancara yang peneliti lakukan terhadap narasumber Fajar Sulaiman selaku Kasubbdit Merek dan IG pada Dirjen KI Kemenkumham RI. Bentuk perlindungan tersebut selanjutnya dijabarkan dalam BAB XI Pasal 70 UU Nomor 20 Tahun 2016, yaitu dalam bentuk Pembinaan dan Pengawasan IG. Adapun bunyi dari pasal tersebut adalah sebagai berikut:

Pasal 70

(1) "Pembinaan IG dilakukan oleh pemerintah pusat dan/atau pemerintah daerah sesuai dengan kewenangannya".

(2) "Pembinaan sebagaimana dimaksud pada ayat (1), meliputi":

a. "persiapan untuk pemenuhan persyaratan Perrnohonan Indikasi Geografis";

b. "Permohonan pendaftaran IG";

c. "pemanfaatan dan komersialisasi IG";

d. "sosialisasi dan pemahaman atas pelindungan $I G$ ";

e. "pemetaan dan inventarisasi potensi produk IG";

f. "pelatihan dan pendarnpingan"

g. "pernantauan, evaluasi, dan pembinaan";

h. "pelindungan hukum"; dan "fasilitasi pengembangan, pengolahan, dan pemasaran barang dan/ atau produk $I G "$.

\section{Pasal 71}

"Pembinaan IG dilakukan oleh pernerintah pusat dan/atau pemerintah daerah sesuai dengan kewenangannya”.

Menurut penjelasan dari narasumber yaitu Kadiv Yankum dan HAM pada Kanwil kemenkumham Kepri, Kabid Yankum dan Kasubbid Yan KI dikarenakan sampai dengan saat ini baru terdapat (satu) potensi produk IG dari Kepri yang sudah didaftarkan pada Direktorat Jenderal Kekayaan Intelektual, maka pasca suatu produk ditetapkan sebagai produk IG, perlu dilakukan pengawasan dari Kanwil Kemenkumham Kepri, khususnya terhadap kualitas mutu yang baik terhadap produk yang dikeluarkan, seperti "Sagu Lingga". Hal ini dilakukan agar dipasaran tidak ada produk yang kualitasnya di bawah standar atau terjadi penurunan kualitas. Apabila hal ini terjadi, maka konsekuensinya adalah produk yang dikembangkan dengan IG tersebut tidak akan dipercayai oleh konsumen. Pengawasan tersebut dapat dilakukan melalui koordinasi dengan MPIG yang ada di setiap daerah.

Akan tetapi, lahirnya ketentuan Pasal 70 ayat (1) UU Nomor 20 Tahun 2016 tersebut juga menurut peneliti kurang menekankan sejauh mana pembagian tanggungjawab dalam hal pembinaan maupun pengawasan yang dapat dilakukan oleh pemerintah pusat maupun Pemda. Dalam rumusan Pasal 70 ayat (2) dan Pasal 71 ayat (1) hanya menyebutkan secara umum. Hal ini kedepannya akan bersifat bisa untuk dilaksanakan oleh Ditjen KI, Kanwil maupun Pemda. Sehingga Kanwil 
Kemenkumham tidak secara rutin melakukan pengawasan di daerah terhadap potensi maupun produk yang telah didaftarkan sebagai IG.

Dalam upaya perlindungan terhadap potensi produk IG yang ada di Kepri, bahwa Kanwil Kemenkumham Kepri telah melaksanakan tugasnya yang berkaitan dengan pembinaan dan penagwasan sebagaimana telah diamanatkan dalam Undang-Undang Nomor 20 Tahun 2016. Berdasarkan hasil penelitian di lapangan, bahwa diawali dengan komitmen dalam memenuhi target kinerja Kemenkumham sebagaimana telah ditetapkan untuk setiap tahunnya. Hal ini terbukti dari hasil penelitian dokumen yang peneliti lakukan terhadap Surat Keputusan Kakanwil Kemenkumham Kepri Nomor W.32.117.UM.01.01 Tahun 2019 Tentang Panitia Kegiatan Pengawasan IG Terdaftar. Dimana dalam keputusan tersebut telah secara jelas menetapkan panita dari internal Kanwil untuk melakukan pengawasan terhadap IG Terdaftar. Selanjutnya, peran tersebut juga didukung dengan hasil wawancara dengan Kadivyankum dan HAM yang menyebutkan bahwa salah satu fungsi yang berkaitan dengan KI sebagaimana ditetapkan dalam Permenkumham No.30 Tahun 2018 tentang Orta Kanwil adalah melaksanakan pelayanan di bidang AHU, KI, dan pemberian informasi hukum. Dan untuk pertama kalinya pada tahun 2017, Kanwil telah membentuk tim IG yang ditetapkan oleh Kepala Kanwil untuk menemukan potensi IG di Provinsi Kepri.

Selain upaya tersebut, dalam upaya mendorong adanya potensi serta pendaftaran produk IG yang ada di Kepri, Kanwil Kemenkumham telah melakukan upaya sebagai berikut:

1) Berkoordinasi dengan Pemda di Provinsi Kepri; Yang dimaksud dengan pemerintah daerah dalam hal ini adalah" kepala daerah sebagai unsur penyelenggara Pemerintahan Daerah yang memimpin pelaksanaan urusan pemerintahan yang menjadi kewenangan daerah otonom di Provinsi Kepri yang terdiri dari 7 (tujuh) kabupaten/kota". Koordinasi diawali dengan penyampaian surat tertulis kepada stakeholder terkait dan melakukan audiensi dengan Sekretariat Daerah, Dinas Pertanian serta perwakilan masyarakat di Kab. Lingga, Kab. Natuna, Kab. Karimun, Kab. Kepulauan Anambas, Kota Batam dan Kota Tanjungpinang. Audiensi tersebut dimaksudkan untuk menjelaskan sejauh mana tugas dan fungsi Kemenkumham dalam memberikan mewujudkan perlindungan atas hak kekayaan intelektual bagi seluruh masyarakat dan peningkatan pembangunan daerah. Selanjutnya dari hasil koordinasi tersebut Kanwil Kemenkumham menyampaikan tujuannya terkait urgensi perlindungan terhadap potensi produk IG, sehingga perlu dilakukan pendaftaran sedini mungkin, sehingga pemerintah daerah bersedia untuk bekerja sama dengan Kanwil dalam menemukan paling sedikit 1 (satu) potensi IG setiap tahunnya.

2) Memberikan sosialisasi kepada terkait urgensi perlindungan hukum terhadap produk IG yang merupakan bagian dari KI Komunal kepada Pemda dan masyarakat; Selain berkoordinasi secara langsung, dalam upaya pendaftaran potensi produk IG di Kepri, Kanwil Kemenkumham Kepri juga melakukan penyebarluasan informasi terkait tugas dan fungsi Kementerian Hukum dan HAM melalui DJKI yang dilaksanakan oleh Kanwil kepada masyarakat, 
terutama petani sagu Lingga. Sosialisasi tersebut dalam bentuk penyampaian persyaratan serta tahapan apa saja yang perlu diketahui oleh Pemerintah Daerah dan juga khalayak masyarakat yang berkaitan dengan pengetahuan umum tentang KI yang meliputi Merek, Cipta,Paten, IG dan sebagainya.

3) Memberikan informasi dan pendampingan kepada Masyarakat Perlindungan Indikasi Geografis (MPIG) terkait mekanisme pendaftaran IG dan besaran biaya PNBP terkait IG merupakan bagian dari peran dan tanggungjawab yang dilakukan oleh Kanwil Kemenkumham Kepri dimana penjelasan yang disampaikan oleh Kepala subbidang KI. Bahwa terdapat biaya yang perlu diketahui oleh Pemerintah Daerah untuk mendaftarkan KI komunal, seperti halnya yang telah dilaksanakan oleh Pemda Kabupaten Lingga dalam mendaftarkan produk IG Sagu Lingga. Besaran tarif pendapatan Negara bukan paak tersebut adalah sebagaimana diatur dalam PP No.46 Tahun 2016 Tentang Perubahan Atas PP No. 45 Tahun 2014 tentang PNBP Pada Kemenkumham.

4) Mengarahkan pembentukan dan melakukan pengawasan terhadap MPIG; adanya MPIG merupakan salah satu syarat yang diwajibkan dalam permohonan pendafratan produk IG, namun berdasarkan hasil wawancara dengan Dinas Pertanian Kabupaten Lingga, bahwa saat ini di daerah belum terdapat MPIG. Untuk itu, Kanwil Kemenkumham telah berupaya untuk mengarahkan pembentukan MPIG di Kabupaten Lingga yang dikenal dengan nama PPSI Cabang Lingga. Namun untuk kabupaten/kota yang lain di Kepri memang belum terdapat sama sekali MPIG.

5) Menginventarisasi potensi IG di daerah; Untuk mengetahui ada atau tidaknya suatu potensi produk IG di daerah, salah satu peran yang telah dilakukan oleh Kanwil Kemenkumham Kepri adalah melakukan inventarisasi terhadap produk yang memiliki nilai "unggul" yang berasal dari masyarakat dan pemerintah daerah.

\section{b. Kendala Yang Dihadapi Kanwil Dalam Pendaftaran Potensi IG}

Dalam upaya pendaftaran potensi produk IG yang ada di Provinsi Kepri, Kanwil Kemenkumham Kepri juga menghadapi berbagai kendala, baik yang berasal dari internal maupun eksternal. Jika dikaji menggunakan teori Efektifitas Hukum yang dikemukakan oleh pendapat ahli, Soerjono Soekanto, yang menyatakan bahwa "efektif adalah taraf sejauh mana suatu kelompok dapat mencapai tujuannya". Menurutnya suatu hukum dapat dikatakan efektif, apabila terdapat dampak hukum yang positif, pada saat itu hukum mencapai sasarannya dalam membimbing ataupun merubah perilaku manusia sehingga menjadi perilaku hukum. Sehubungan dengan persoalan efektivitas hukum, pengidentikkan hukum tidak hanya dengan unsur paksaan eksternal namun juga dengan proses pengadilan. Ancaman paksaan pun merupakan unsur yang mutlak ada agar suatu kaidah dapat dikategorikan sebagai hukum, maka tentu saja unsur paksaan inipun erat kaitannya dengan efektif atau tidaknya suatu ketentuan atau aturan hukum.

Membicarakan tentang efektivitas hukum berarti membicarakan daya kerja hukum itu dalam mengatur dan atau memaksa masyarakat untuk taat terhadap hukum. Hukum dapat efektif jikalau faktor-faktor yang mempengaruhi hukum 
tersebut dapat berfungsi dengan sebaik-baiknya. Ukuran efektif atau tidaknya suatu peraturan perundang-undangan yang berlaku dapat dilihat dari perilaku masyarakat. Suatu hukum atau peraturan perundang-undangan akan efektif apabila warga masyarakat berperilaku sesuai dengan yang diharapkan atau dikehendaki oleh atau peraturan perundang-undangan tersebut mencapai tujuan yang dikehendaki, maka efektivitas hukum atau peraturan perundang-undangan tersebut telah dicapai.

Salah satu kendala yang dihadapi oleh Kanwil Kemenkumham Kepri dalam memaksimalkan pendaftaran potensi produk IG tidak terlepas dari payung hukum yang mendasari pengaturan terkait penyelenggaraan perlindungan IG di Indonesia sebagaimana telah ditetapkan dan diatur dalam PP 51 Tahun 2007 dan Permenkumham 12 Tahun 2019, dimana setiap barang maupun produk yang dihasilkan baik orang perorangan maupun komunitas (kelompok masyarakat) yang memiliki potensi untuk didaftarkan sebagai IG harus memenuhi prosedur dan persyaratan yang cukup banyak. Sebagai contoh, mengacu pada hasil wawancara dengan Kadivyankum dan HAM, yaitu bapak Darsyad, Kasubbid KI dan PPSI Cabang Lingga serta Dinas Pertania Kab/Lingga, bahwa komunitas Petani Sagu yang berada di bawah nagungan PPSI kesulitan untuk menyiapkan buku persyaratan "Sagu Lingga" yang mengharuskan adanya deskripsi atau uraian mengenai sejarah, manfaat, gambaran detail, peta wilayah atau batas daerah dan manfaat serta mekanisme dari mulai proses produksi, pengolahan dan pendistribusian potensi produk IG yang akan didaftarkan pada DJKI, selain itu dalam PP No. 46 Tahun 2016 tentang Perubahan Atas PP No.45 Tahun 2014 tentang "PNBP yang berlaku Pada Kemenkumham" menetapkan biaya pendafataran IG Komunal sebesar Rp 500.000,-. Hal ini membuat beberapa Pemerintah Daerah yang ada di Kepri, seperi Kab.Karimun, Kab.Bintan, Kab.Batam dan Kab.Natuna menunda proses pendaftaran potensi produk unggulan yang di daerah tersebut diantaranya tenun Batam, rambutan dari Tanjungbatu, cengkeh atau lada putih dan madu.

Provinsi Kepri merupakan daerah kepulauan yang memiliki kondisi geografis cukup berbeda dengan provinsi daratan, dengan kondisi hampir 99\% wilayahnya dikelilingi oleh lautan, maka tidak heran jika wilayah administratifnya terpisah oleh pulau dan rentang jarang puluhan bahkan ratusan mil. Sebut saja pulau terluar Kabupaten Natuna dan Kep.Anambas yang jauh dari jangkauan. Kondisi ini menjadi salah satu kendala atau hambatan yang membuat peran Kanwil Kumham dalam upaya pendaftaran potensi produk IG di Prov.Kepri tidak dilaksanakan secara efektif. Untuk melakukan koordinasi dan peninjauan dalam menemukan suatu potensi produk IG dapat membebani anggaran Negara yang cukup, karena tim investigasi IG harus turun langsung ke lapangan untuk melihat keberadaan dan gambaran potensi produk tersebut apakah telah didukung oleh persyaratan yang telah ditetapkan dalam UU 8/2016.

Dalam mendukung pelaksanaan suatu hal yang berkaitan dengan tanggungjawab, peran Kanwil Kemenkumham juga bergantung pada besar/kecilnya anggaran yang disediakan oleh pemerintah. Berdasarlkan pengalaman narasumber, bahwa anggaran yang dialokasikan untuk subbidang KI sangatlah minim, sehingga upaya dalam bentuk koordinasi secara langsung yang 
harusnya dapat dilakukan oleh Kanwil dengan pemda setempat tidak berjalan maksimal.

Minimnya pengetahuan masyarakat terhadap kegunaan dan manfaat hasil karya berupa barang maupun produk hasil ciptaan masyarakat yang sehari-hari ditemui dan ternyata sangat berkaitan dengan produk yang dapat dinyatakan sebagain IG, dari hasil wawancara yang peneliti lakukan dengan Kasubbid KI bahwa berdasarkan inventarisasi yang dilakukan oleh Tim Pengawas IG Kanwil Kemenkumham Kepri dari tahun 2017 sampai dengan tahun 2019 tepatnya sejak pemberlakuan UU 8/2016 dan penetapan target kinerja Kanwil untuk menemukan paling sedikit 1 (satu) produk IG di masing-masing provinsi, peneliti telah menyesuaikan dengan hasil wawancara dan observasi di lapangan bahwa masyarakat kurang mengetahui adanya Peran Kanwil Kemenkumham dalam bidang kekayaan intelektual, khususnya IG. Selanjutnya, untuk memudahkan proses inventarisasi dalam rangka pendaftaran potensi produk IG pada Dirjen KI, Kanwil Kepri telah melakukan penandatanganan nota kesepahaman (memorandum of understanding) dengan kabupaten Karimun. Namun perlu diikuti dengan kabupaten/kota lainnya yang ada di provinsi Kepri agar upaya tersebut dapat berjalan optimal.

\section{c. Solusi Untuk Mengatasi Kendala Yang Dihadapi Kanwil Kemenkumham Dalam Pendaftaran IG}

Terhadap kendala yang dihadapi oleh Kanwil Kemenkumham Kepri dalam upaya pendaftaran potensi produk IG yang ada di Kepri perlu adanya solusi. Menurut KBBI, solusi "adalah penyelesaian; pemecahan (masalah, dan sebagainya); jalan keluar untuk suatu kendala atau hambatan atau masalah". Apabila kita hubungkan dengan teori Efektifitas Hukum sebagaimana dikemukakan Soerjono Soekanto, bahwa terhadap faktor-faktor yang menjadi kendala dalam penegakan hukum, khususnya dalam hal ini UU No.20 Tahun 2016 tentang Merek dan IG yang berkaitan dengan peran Kanwil dalam Pendaftaran Potensi IG.

Terhadap kewajiban pemerintah maupun pemerintah daerah khususnya dalam melakukan pembinaan dan pengawasan terhadap produk IG sebagaimana diatur dalam Pasal 70 dan Pasal 71 Undang-Undang Nomor 20 Tahun 2016 perlu dipertegas lagi, khususnya terhadap pelaksanaan kegiatan pembinaan dan pengawasan tersebut secara konkrit yang diatur dalam peraturan pelaksanaan dari UU tersebut berupa peraturan pelaksanaan maupun peraturan menteri yang bersifat teknis. Terkait dengan tugas dan fungsi Kanwil Kemenkumham di bidang kekayaan intelektual sebagaimana yang diatur dalam Permenkumham RI Nomor 30 Tahun 2018 tentang ORTA Kanwil Kemenkumham yang kegiatannya berbasis pada anggaran pada Daftar Isian Penggunaan Anggaran perlu diselaraskan dengan target kinerja yang penetapannya melalui Keputusan Menteri Hukum dan Hak Asasi Manusia Republik Indonesia. Target kinerja Menteri Hukum dan Hak Asasi Manusia yang ditetapkan setiap tahun merupakan suatu bentuk kebijakan publik yang dilakukan oleh seorang pejabat publik untuk mengambil langkah-langkah yang diperlukan dalam rangka demi terwujudnya target-capaian yang diprioritaskan agar terpenuhi demi kepentingan masyarakat/publik. Ini kita kenal pula dengan 
diskresi atau fries emersen. Apabila tercipta keselarasan di antara keduanya maka Kantor Wilayah akan lebih mudah dalam bekerja melaksanakan proses pembinaan dan pengawasan terhadap IG termasuklah di dalamnya dalam upaya mendorong dilakukannya pendaftaran potensi IG.

Perlu adanya sosialisasi, bimbingan teknis serta pembinaan dan pengawasan yang rutin dari Kanwil Kemenkumham Kepri yang bekerjasama dengan Direktorat Jenderal Kekayaan Intelektual, Pemerintah Daerah dan juga masyarakat. Selain itu, Pemerintah Daerah juga perlu menetapkan target kinerja tahunan dan tim inventarisasi potensi produk IG di daerah, agar sejalan dengan target kinerja yang telah ditetapkan oleh pemerintah pusat. Serta diperlukan peningkatan kerjasama atau MoU terkait upaya perlindungan kekayaan intelektual di Provinsi Kepri.

Perlu adanya peningkatan atau penambahan anggaran bagi Kanwil Kemenkumham Kepri untuk melakukan inventarisasi potensi produk IG di kabupate terluar yang ada di Provinsi Kepri, khususnya Kabupaten Natuna dan Kabupaten Kepulauan Anambas.

Perlu adanya peningkatan kesadaran dan pemahaman dari masyarakat, khususnya MPIG untuk menjaga, memlihara serta melindungi potensi produk IG agar tidak ditiru atau diimitasi oleh produk lainnya yang sejenis. Selain itu, masyarakat juga perlu menyadari bahwa manfaat ekonomis yang timbul apabila suatu produk sudah terdaftar pada DJKI bukanlah hal hal instan, melainkan butuh waktu dan pembuktian kualitas produk tersebut di kalangan konsumen dan pasar. Masyarakat perlu diedukasi tentang pentingnya pendaftaran potensi IG karena dapat memberikan manfaat untuk melindungi produk dan produsen dari tindakan penyalahgunaan dan pemalsuan tanda IG, meningkatkan posisi tawar produk serta kemampuan mamasuki pasar baru pada tataran nasional maupun internasional, meningkatkan nilai tambah, membuka lapangan pekerjaan, meningkatkan kualitas produk, meningkatkan produksi, meningkatkan peluang diversivikasi produk, memberikan informasi yang jelas kepada konsumen tentang jenis, kualitas dan asal produk yang mereka beli, meningkatkan peluang promosi untuk memperoleh reputasi yang lebih baik, meningkatkan pendapatan dan kesejahteraan pelaku usaha, meningkatkan ekonomi dan mempercepat pembangunan wilayah, menjaga kelestarian lingkungan untuk menjamin keberadaan ciri dan kualitas produk serta menjaga kelestarian budaya bangsa yang terkait dengan kualitas dan reputasi suartu barang IG.

Untuk memberikan pencerahan atas kebudayan yang berkembang dalam masyarakat khususnya yang berkaitan dengan manfaat instan pendaftaran produk IG, Kanwil Kemenkumham Kepri perlu melakukan sosialisasi dan memberikan pemahaman terhadap kebudayaan masyarakat yang kurang berminat untuk mendaftarkan produk yang berpotensi sebagai produk IG yang berasal dari daerah atau komunitasnya tanpa harus melihat nilai komersilnya terlebih dahulu. Dengan usaha dan gerakan penyadaran yang dilakukan secara bertahap diharapkan dapat mengikis budaya negatif tersebut.

\section{E. Kesimpulan}


Terhadap hasil penelitian ini, dapat diambil kesimpulan sebagai berikut :

a. Terhadap upaya pendaftaran potensi produk IG yang ada di Provinsi Kepri, peran Kantor Wilayah belum maksimal dan masih terbatas pada upaya yang meliputi berkoordinasi dengan Pemerintah Daerah di lingkungan Provinsi Kepri, memberikan sosialisasi kepada Pemda dan masyarakat terkait urgensi perlindungan hukum terhadap produk IG yang merupakan bagian dari KI Komunal, memberikan informasi dan pendampingan kepada MPIG Terkait mekanisme pendaftaran IG dan besaran biaya PNBP terkait IG, mengarahkan pembentukan dan melakukan pengawasan terhadap MPIG, menginventarisir potensi produk IG di daerah; dan melakukan Pembinaan dan pengawasan terhadap pengaruh atau dampak kenaikan harga pasca produk IG didaftarkan.

b. Adapun kendala yang dihadapi oleh Kanwil Kemenkumham Kepri dalam upaya pendaftaran produk IG adalah sebagai berikut:

1) Prosedur dan persyaratan pendafaran IG yang diatur dalam PP No. 51 Tahun 2007, dan Permenkumham No.12 Tahun 2019 membutuhkan biaya dan waktu yang cukup panjang.

2) Kurangnya pengetahuan Pemerintah Daerah setempat serta masyarakat yang ada di Kepri.

3) Minimnya keterlibatan masyarakat dalam membentuk MPIG / tidak semua Kabupaten/Kota memiliki MPIG;

4) Kurangnya respon serta minat pemda dan masyarakat terhadap manfaat IG.

5) Minimnya kegiatan sosialisasi, bimtek dan Rakernis dari DJKI;

6) Belum semua kabupaten/kota melakukan MOU untuk menginventarisasi adanya potensi produk IG; dan

7) Belum adanya target kinerja yang ditetapkan oleh pemerintah daerah untuk memiliki produk IG.

8) Letak geografis kabupaten di Kepri yang cukup jauh; dan

9) Terbatasnya Anggaran untuk melakukan koordinasi secara langsung.

10) Masyarakat kurang percaya dengan perlindungan hukum yang diberikan pemerintah terkait IG, dan hanya berharap dampak secara instan bagi masyarakat.

c. Solusi yang dapat diberikan terhadap kendala yang dihadapi Kanwil Kemenkumham Kepri dalam upaya pendaftaran potensi produk IG di Provinsi Kepri adalah sebagai berikut:

1) Perlu adanya pengaturan yang lebih tegas terhadap kewajiban Pemerintah pusat maupun pemda untuk melakukan membina dan mengawasi penyalahgunaan produk IG.

2) Perlu adanya peningkatan kesadaran dan pemahaman dari masyarakat, khususnya MPIG (IG) untuk menjaga, memlihara serta melindungi potensi produk IG agar tidak ditiru atau diimitasi oleh produk lainnya yang sejenis.

3) Perlu adanya sosialisasi, bimbingan teknis serta pembinaan dan pengawasan yang rutin dari Kanwil Kemenkumham Kepri yang bekerjasama dengan Direktorat Jenderal Kekayaan Intelektual, Pemerintah Daerah dan juga masyarakat. 
4) Perlu adanya peningkatan atau penambahan anggaran bagi Kanwil Kemenkumham Kepri untuk melakukan inventarisasi potensi produk IG di kabupaten terluar yang ada di Provinsi Kepri, khususnya Kabupaten Natuna dan Kabupaten Kepulaluan Anambas.

5) Perlu adanya sosialisasi rutin dan pemahaman terhadap kebudayaan masyarakat yang kurang berminat untuk mendaftarkan produk di daerah yang memilik potensi mejadi produk IG yang berasal dari daerah atau komunitasnya tanpa harus melihat nilai komersilnya terlebih dahulu. 


\section{DAFTAR PUSTAKA}

\section{Buku-buku}

Achmad Ali. Menguak Teori Hukum (Legal Theory) dan Teori Peradilan (Judicial Prudence) Termasuk Interpretasi Undang-Undang (Legisprudence). Jakarta: Penerbit Kencana. 2009.

Ahmad M. Ramli, Miranda Risang Ayu Palar, S.H., LL.M, Ph.D, Kekayaan Intelektual Pengantar Indikasi Geografis, Penerbit Alumni, Bandung, 2018.

Amiruddin, Pengantar Metode Penelitian Hukum, Jakarta: PT. Raja Grafindo Persada, 2012.

Erman Rajagukguk, Filsafat Hukum, Universitas Indonesia Fakultas hukumPascasarjana, Jakarta: 2017.

Iswi Hariyani, Prosedur Mengurus HKI Yang Benar, Pustaka Yustisia, Yogyakarta, 2010.

Lili Rasjidi dan Ira Thania Rasjidi, Dasar-Dasar Filsafat dan Teori Hukum, PT. Citra Aditya Bakti, bandung, 2004.

Miranda Risang Ayu, Memperbincangkan Hak Kekayaan Intelektual Indikasi Geografis, PT. Alumni, Bandung, 2006.

Muhammad Firmansyah, Tata Cara Mengurus Hak Kekayaan Intelektual, Jakarta : Visimedia, 2008.

Mochtar Kusumaatmadja, Konsep-konsep Hukum dalam Pembangunan Nasional, Penerbit Alumni, Bandung, 2002.

Mochtar Kusumaatmadja, Konsep-konsep Hukum dalam Pembangunan Nasional, Penerbit Alumni, Bandung, 2002.

Otje Salman S, dan Anthon F. Susanto, Teori Hukum, Mengingat, Mengumpulkan dan Membuka Kembali, Refika Aditama, Bandung, 2004.

Otto Hasibuan, Hak Cipta di Indonesia, Alumni Bandung, 2008.

Peter Damary, Modul Pelatihan Indikasi Geografis, Indonesian-Swiss Intellectual Property Project, 2018.

Soerjono Soekanto. Faktor-Faktor yang Mempengaruhi Penegakan Hukum. Jakarta. Penerbit PT. Raja Grafindo Persada. 2007.

Soerjono Soekanto, Pengantar Penelitian Hukum, Jakarta: Rajawali Pers, 1996.

Sugiyono, Metode Penelitian Kuantitatif Kualitatif dan R\&D, Bandung: Alfabeta, 2008.

Suyud Margono, Aspek Hukum Komersialisasi Aset Intelektual, Nuansa Aulia, Bandung, 2010. 
Tomy Suryo Utomo, Hak Kekayaan Intelektual (HKI) di Era Global, Graha Ilmu, Yogyakarta, 2010.

Winda Rina Yessiningrum, Perlindungan Hukum Indikasi Geografis Sebagai Bagian Dari Hak Kekayaan Intelektual, Jurnal IUS Vol III Nomor 7 April 2015.

\section{Artikel Jurnal}

Kamus Besar Bahasa Indonesia (KBBI)

Agung Darmarsasongko, Perlindungan Indikasi Geografis di Indonesia, Penelitian pada Program Pasca Sarjana Sekolah Tinggi Ilmu Hukum "IBLAM", Jakarta, 2002.

Ditjen HKI (Bekerja sama dengan EC-ASEAN IPRs Co-operation Programme (ECAP II), Buku Panduan Hak Kekayaan Intelektual Dilengkapi dengan Peraturan Perundang-Undangan Di Bidang Hak Kekayaan Intelektual, Jakarta, ditjen HKI-ECAP II, 2006.

Sri Soemantri M, Makalah Seminar "50 Tahun Kemandirian Kekuasaan Kehakiman diIndonesia", FH-UGM,1995.

Zulfi Diane Zaini, Perspektif Hukum sebagai Landasan Pembangunan Ekonomi Di Indonesia (sebuah pendekatan Filsafat), Jurnal Hukum Vol. XXVIII, No. 2 Desember 2012.

\section{Wawancara}

Wawancara dengan Kepala Sub Direktorat Merek dan Indikasi Geografis pada Direktorat Jenderal Kekayaan Intelektual Kementerian Hukum dan Hak Asasi Manusia Republik Indonesia, pada tanggal 14 Agustus 2019.

Wawancara dengan Kepala Divisi Pelayanan Hukum dan HAM Kanwil Kemenkumham Kepri, pada tanggal 14 Agustus 2019.

Wawancara dengan Kepala Bidang Pelayanan Hukum dan HAM Kanwil Kemenkumham Kepri, pada tanggal 10 September 2019.

Wawancara dengan Kasubbid KI Kanwil Kemenkumham Kepri, pada tanggal 11 September 2019.

Wawancara dengan Bapak Zulhamdi, pada tanggal 27 September 2019.

Wawancara dengan Pengurus Perhimpunan Pendayaguna Sagu Indonesia Cabang Lingga, tanggal 27 September 2019. 
Wawancara dengan Ketua Pengurus Perhimpunan Pendayaguna Sagu Indonesia Cabang Lingga, pada tanggal 12 September 2018.

\section{Internet}

Iffa Rohmah. 2016. Penegakkan Hukum. http://pustakakaryaifa.blogspot.com. Diakses : Pukul 12.00 WIB, Tanggal 1 Februari 2019.

http://m.airlines.web.id/id3/114-11/Negara-egadiversitas_101629_airlines.html, diakses pada tanggal 02 November 2019.

http://antarberita.blogspot.com/2013/09/pengertian-efektivitas-dan-efisiensi.html, Putera Gembala, Minggu, 1 September 2013 diakses pad tanggal 1 Februari 2019 pukul 10.00 WIB.

WIPO, “GeographicalIndications,"http://www.wipo.int/aboutip/en/geographical_i nd.html, diakses tanggal 22 Januari 2019.

https://www.kitapunya.net/2018/03/pengertian-merek-menurut-para-ahli.html diakses pada tanggal 25 Januari 20189 jam 17.00 WIB.

https://www.hukumonline.com/berita/baca/lt5ab34123cf623/dirjen-ki-targetkan1000-pendaftaran-indikasi-geografis-dalam-negeri--peluang-barukonsultan-hki/ diakses pada tanggal 20 Agustus 2019.

https://www.kajianpustaka.com/2014/01/pengertian-indikator-faktor mempengaruhi-kinerja.html?m=1 pada tanggal 19 Oktober 2019.

http://umum-pengertian.blogspot.com/2016/06/pengertian-peran-secaraumum.html, tanggal 12 November 2019.

\section{Peraturan Perundang-undangan}

Undang-Undang Nomor 7 Tahun 1994 Tentang Pengesahan Agreement Establishing The World Trade Organization (Persetujuan Pembentukan Organisasi Perdagangan Dunia), LN Tahun 1994 Nomor 57, TLN Nomor 3564.

UU Nomor 23 Tahun 2014 Tentang Pemerintahan Daerah sebagaimana telah diubah beberapa kali terakhir dengan Undang-Undang Nomor 9 Tahun 2015.

Undang-Undang Nomor 20 Tahun 2016 tentang Merek dan Indikasi Geografis.

Permenkumham Nomor 29 Tahun 2015 Tentang Organisasi dan Tata Kerja Kementerian Hukum dan Hak Asasi Manusia Republik Indonesia. 
Peraturan Menteri Hukum dan Hak Asasi Manusia Republik Indonesia Nomor 30 Tahun 2018 tentang Organisasi dan Tata Kerja Kantor Wilayah Kementerian Hukum dan Hak Asasi Manusia.

Peraturan Menteri Hukum dan Hak Asasi Manusia Republik Indonesia Nomor 12 Tahun 2019 tentang Indikasi Geografis.

Keputusan Menteri Hukum dan Hak Asasi Manusia Republik Indonesia Nomor M.HH-01.PR.01.03 Tahun 2017 tentang Tarja Kemenkumham RI Tahun 2018. 